\title{
Controle de políticas públicas pelos tribunais de contas: tutela da efetividade dos direitos e deveres fundamentais ${ }^{*}$
}

Daniela Zago Gonçalves Cunda ${ }^{1}$

\section{Resumo}

O presente artigo, por meio dos métodos dedutivo e sistêmico, pretende demonstrar as vantagens de uma proporcional interação entre o direito, as políticas públicas, os princípios, direitos e deveres fundamentais e o controle externo a ser exercido pelos Tribunais de Contas, com ênfase nos direitos fundamentais, à saúde e à educação (e correlato desenvolvimento social), bem como ao princípio fundamental da dignidade da pessoa humana (desenvolvimento humano). O estudo apresentado propõe uma interpretação conjunta (tópico-sistemática) dos dispositivos constitucionais que determinam a competência dos Tribunais de Contas (art. 71 e seguintes) em cotejo com os princípios (art. 1. ${ }^{\circ}$ ) e objetivos fundamentais (art. 3. ${ }^{\circ}$ ), além dos princípios da administração pública (art. 37, todos da Constituição Federal), com ênfase no princípio da eficiência (intimamente ligado ao direito fundamental à boa administração pública) e não somente no princípio da legalidade. A abordagem destaca a otimização da aplicação dos recursos orçamentários rumo à ampliação do mínimo existencial, no que se refere aos direitos fundamentais sociais (em especial o direito à saúde e à educação), de maneira a contornar a escassez de recursos. Conjuntamente, são apresentadas breves considerações sobre os Tribunais de Contas no contexto nacional e internacional, considerações a respeito do controle das políticas públicas e alguns destaques das finanças públicas a serviço dos direitos fundamentais. O ensaio proposto é uma singela demonstração da von-

Artigo recebido em: 30/09/2010.

Artigo aprovado em: 09/11/2010.

1 Mestranda em Direito na PUC-RS. Graduada em Direito pela Universidade Federal de Santa Maria, com especialização em Direito Público - UFRGS. Docência em cursos preparatórios para concursos e exame da OAB (Escola Superior de Advocacia - ESA/OAB, UCS, ITEC, CETRA, dentre outros que já atuou como professora) e professora-tutora do Curso de Preparação à Magistratura a Distância (CPMD-AJURIS). Auditora Pública do Tribunal de Contas do Estado do Rio Grande do Sul. 
tade de tornar nossa Constituição Federal uma realidade palpitante, visando, além de integrá-la ao nosso cotidiano existencial, tutelar o mínimo existencial nela previsto e ainda com a pretensão de ampliá-lo, por meio da otimização orçamentária, com ênfase nos recursos vinculados em educação e saúde, tudo sob a ótica especial do direito fundamental à boa administração pública. Para atingir tal propósito, o controle das políticas públicas pelos Tribunais de Contas se demonstra ferramenta indispensável, não apenas cingindo-se a um controle da legalidade, indo além, de maneira a zelar o cumprimento de princípios, direitos e deveres fundamentais.

Palavras-chave: Políticas públicas. Controle. Tribunais de Contas. Direitos fundamentais.

\section{Introdução}

Um dos objetivos do presente estudo é o de trazer para debate nos Tribunais de Contas ${ }^{2}$ o enfrentamento consciente de vários conceitos atinentes à Teoria Geral dos Direitos Fundamentais e questões relacionadas ao controle das políticas públicas, com proporcionalidade, indispensáveis para uma assumida tutela dos direitos e deveres fundamentais pelas Cortes de Contas. Da mesma forma, pretende-se submeter aos estudos acadêmicos a missão institucional dos Tribunais de Contas e de que forma a referida instituição poderia contribuir para a concretização dos princípios e direitos fundamentais constantes (explícita e implicitamente) em nossa Carta Constitucional.

Há consenso de que o Estado tem obrigação de assegurar a dignidade da pessoa humana (um dos princípios fundamentais constante já no art. $10^{\circ}$ da Constituição Federal) e compensar as desigualdades sociais, por meio de políticas e serviços públicos, de maneira a efetivar os direitos sociais. Justamente, nesse cenário, a existência de um órgão controlador configura-se como um verdadeiro instrumento de defesa da sociedade em relação ao Estado, como garantia da submissão

2 Embora se vislumbre nas decisões dos referidos tribunais certo zelo por várias modalidades de direitos fundamentais. 
deste aos princípios e regras impostos pela Constituição Federal, com a pretensão última de alcançar a justiça social e superar as desigualdades.

O catálogo brasileiro dos objetivos fundamentais (art. 3. ${ }^{\circ}$ da Constituição Federal) prevê uma sociedade livre, justa e solidária, além da erradicação das desigualdades sociais e a promoção do bem de todos. Também sob essa ótica, deverá ser a atuação dos Tribunais de Contas na tutela dos direitos fundamentais.

Impera, portanto, a necessidade de uma interpretação tópico-sistemática, ${ }^{3}$ ou seja, conjunta dos dispositivos constitucionais que determinam a competência dos Tribunais de Contas (art. 71 e seguintes) em cotejo com os princípios (art. 1. ${ }^{\circ}$ ) e objetivos fundamentais (art. 3. ${ }^{\circ}$ ), além dos princípios da administração pública (art. 37, todos da Constituição Federal de 1988), com ênfase no princípio da eficiência (intimamente ligado ao direito fundamental à boa administração pública) e não somente no princípio da legalidade.

Os direitos sociais (em especial os prestacionais) e respectivas políticas públicas para realizá-los são objeto de controle dos Tribunais de Contas, como a pre-

3 O método de interpretação jurídica empregado será o tópico-sistemático, verdadeiramente a interpretação sistemática, compreendida em novas e realistas bases, é a que se realiza em consonância com aquela rede hierarquizável, máxime na Constituição, tecida de princípios, regras e valores considerados dialeticamente e em conjunto na interação com o intérprete, positivador derradeiro FREITAS, Juarez. A Interpretação sistemática do direito. 5. ed., São Paulo: Malheiros, 2010. Maiores detalhes na nota 53.

Nessa linha, propõe-se uma interpretação conjunta dos dispositivos constitucionais que determinam a competência dos Tribunais de Contas (art. 71 e seguintes) em cotejo com os princípios (art. 1..$^{\circ}$ ) e objetivos fundamentais (art. 3. ${ }^{\circ}$ ), além dos princípios da administração pública (art. 37, todos da Constituição Federal), com ênfase no princípio da eficiência (intimamente ligado ao direito fundamental à boa administração pública) e não somente no princípio da legalidade. Conjuntamente, mediante uma interpretação tópico-sistemática dos artigos 34, inc. VII, “e”, e 35, inc. III, da Constituição Federal (que tratam da previsão de intervenção quando da não-aplicação dos recursos mínimos em educação e saúde) em conjunto com os demais dispositivos constitucionais que tutelam o direito fundamental à educação e à saúde - em especial os que determinam os percentuais mínimos a serem aplicados, como o art. 212 da Constituição Federal e o art. 77 do ADCT e a Emenda Constitucional n. 29/00 - (pelo que permite o art. 198 da CF) impera-se a visualização no sentido de que os referidos direitos fundamentais sociais prestacionais assumem uma maior densidade normativa de maneira a atingir um maior grau de eficácia. 
vidência social (registro dos atos de aposentadoria e pensões), a saúde e educação (na análise da aplicação dos percentuais mínimos estabelecidos na Constituição Federal), o meio ambiente (mediante a realização de auditorias operacionais), dentre tantos outros enfoques relacionados diretamente aos direitos fundamentais.

No presente ensaio, a abordagem esboçará algumas considerações sobre a otimização da aplicação dos recursos orçamentários rumo à ampliação do mínimo existencial, no que se refere aos direitos fundamentais (com ênfase no direito à saúde e à educação), de maneira a contornar a escassez de recursos, tudo sob a ótica do princípio da eficiência.

Cada vez mais, assume relevância a necessidade de o controle público abordar o direito fundamental à boa administração pública e focalizar-se na correlação entre "boa política" e "boa finança". Os primeiros passos nesse sentido têm sido dados pelo Tribunal de Contas da União e de alguns Tribunais de Contas estaduais de nosso país. No mesmo rumo, direcionam-se várias Cortes de Contas da União Europeia (como a de Portugal, da Itália, da França e da Alemanha), de maneira a tutelar os valores previstos nos princípios republicanos. 


\title{
2 Breves considerações sobre os Tribunais de Contas
}

\author{
Partindo-se do pressuposto de um prévio conhecimento das competências \\ dos Tribunais de Contas, tanto da União ${ }^{4}$ como dos
}

4 Constituição Federal de 1988. Art. 71. O controle externo, a cargo do Congresso Nacional, será exercido com o auxílio do Tribunal de Contas da União, ao qual compete:

I - apreciar as contas prestadas anualmente pelo Presidente da República, mediante parecer prévio que deverá ser elaborado em sessenta dias a contar de seu recebimento;

II - julgar as contas dos administradores e demais responsáveis por dinheiros, bens e valores públicos da administração direta e indireta, incluídas as fundações e sociedades instituídas e mantidas pelo Poder Público federal, e as contas daqueles que derem causa a perda, extravio ou outra irregularidade de que resulte prejuízo ao erário público;

III - apreciar, para fins de registro, a legalidade dos atos de admissão de pessoal, a qualquer título, na administração direta e indireta, incluídas as fundações instituídas e mantidas pelo Poder Público, excetuadas as nomeações para cargo de provimento em comissão, bem como a das concessões de aposentadorias, reformas e pensões, ressalvadas as melhorias posteriores que não alterem o fundamento legal do ato concessório;

IV - realizar, por iniciativa própria, da Câmara dos Deputados, do Senado Federal, de Comissão técnica ou de inquérito, inspeções e auditorias de natureza contábil, financeira, orçamentária, operacional e patrimonial, nas unidades administrativas dos Poderes Legislativo, Executivo e Judiciário, e demais entidades referidas no inciso II;

$\mathrm{V}$ - fiscalizar as contas nacionais das empresas supranacionais de cujo capital social a União participe, de forma direta ou indireta, nos termos do tratado constitutivo;

VI - fiscalizar a aplicação de quaisquer recursos repassados pela União mediante convênio, acordo, ajuste ou outros instrumentos congêneres, a Estado, ao Distrito Federal ou a Município;

VII - prestar as informações solicitadas pelo Congresso Nacional, por qualquer de suas Casas, ou por qualquer das respectivas Comissões, sobre a fiscalização contábil, financeira, orçamentária, operacional e patrimonial e sobre resultados de auditorias e inspeções realizadas; VIII - aplicar aos responsáveis, em caso de ilegalidade de despesa ou irregularidade de contas, as sanções previstas em lei, que estabelecerá, entre outras cominações, multa proporcional ao dano causado ao erário;

IX - assinar prazo para que o órgão ou entidade adote as providências necessárias ao exato cumprimento da lei, se verificada ilegalidade;

$\mathrm{X}$ - sustar, se não atendido, a execução do ato impugnado, comunicando a decisão à Câmara dos Deputados e ao Senado Federal;

XI - representar ao Poder competente sobre irregularidades ou abusos apurados.

$\$ 1^{\circ}$ - No caso de contrato, o ato de sustação será adotado diretamente pelo Congresso Nacional, que solicitará, de imediato, ao Poder Executivo as medidas cabíveis.

$\$ 2^{\circ}$ - Se o Congresso Nacional ou o Poder Executivo, no prazo de noventa dias, não efetivar as medidas previstas no parágrafo anterior, o Tribunal decidirá a respeito.

$\$ 3^{\circ}$ - As decisões do Tribunal de que resulte imputação de débito ou multa terão eficácia de título executivo.

$\$ 4^{\circ}$ - O Tribunal encaminhará ao Congresso Nacional, trimestral e anualmente, relatório de suas atividades. 
Estados, ${ }^{5}$ que exercem o controle externo, essencial um primeiro esclarecimento: trata-se de instituição com autonomia e não de mero órgão auxiliar.

Levando-se em consideração a tendência pós-positivista ${ }^{6}$ em que se visualiza o direito, não apenas como um conjunto de regras, mas como um conjunto de princípios e regras, assumem realce outros princípios $^{7}$ além (e não de maneira a excluí-lo) do princípio da legalidade, como o princípio da eficiência, da celeridade e da proporcionalidade, dentre tantos outros ${ }^{8}$ indispensáveis à tutela do direito fundamental à boa administração pública. ${ }^{9}$ Essa nova dimensão do direito é o que Luciano Ferraz, utilizando-se de uma metáfora, denominou de arco-íris normativo. ${ }^{10}$

5 Art. 75. As normas estabelecidas nesta seção aplicam-se, no que couber, à organização, composição e fiscalização dos Tribunais de Contas dos Estados e do Distrito Federal, bem como dos Tribunais e Conselhos de Contas dos Municípios.

Parágrafo único. As Constituições estaduais disporão sobre os Tribunais de Contas respectivos, que serão integrados por sete Conselheiros.

6 Trata-se do chamado constitucionalismo emancipatório, na feliz expressão de Clèmerson Clève, que destaca a necessidade de se valer da valorização do caráter principiológico e normativo da Constituição para, em vez de se adaptar à realidade concreta, fazer com que a realidade se transforme, conforme pondera MOTTA, Fabrício. Tribunais de Contas e a efetivação dos direitos fundamentais. Revista Del Rey Jurídica, Belo Horizonte, v. 7, n. 14, p. 36-37, 1. sem. 2005.

7 E nesse ponto remete-se aos estudos dos "preceitos para uma interpretação sistemática da Constituição", abordados por FREITAS, Juarez. A Interpretação sistemática do direito. 5. ed. São Paulo: Malheiros, 2010.

8 Como meio de aprofundar o catálogo dos princípios fundamentais regentes das relações de Administração Pública: FREITAS, Juarez. O controle dos atos administrativos e os princípios fundamentais. 4. ed. São Paulo: Malheiros, 2009.

9 Especificamente sobre o tema, indispensável uma leitura da obra de FREITAS, Juarez. Discricionariedade administrativa e o direito fundamental à boa administração pública. 2. ed. São Paulo: Malheiros, 2009.

${ }^{10}$ Luciano Ferraz, em palestra ministrada no III Seminário de Direito Administrativo Controle das Políticas Públicas - Proteção do Usuário palestra publicada na Revista de Direito Administrativo n. 239 de jan./mar. 2005. 
É nesse contexto, que os Tribunais de Contas têm de se inserir, ao cumprir suas atribuições previstas na Constituição, ${ }^{11}$ no exercício de um novo controle externo, ${ }^{12}$ utilizando-se de modernos mecanismos, como o termo de ajustamento de gestão, auditorias operacionais, audiências públicas, intercomunicação entre as instituições, dentre outros a serem desenvolvidos de maneira a melhor tutelar os direitos fundamentais. Nessa seara, além de propiciar um controle voltado para um conjunto de medidas adotadas pela administração para implementar a efetividade de direitos fundamentais, ${ }^{13}$ deixará de ser um controle que somente busca detectar falhas e aplicar sanções, mas que também diagnosticará de maneira mais célere eventuais irregularidades apresentando as respectivas sugestões de soluções (de

${ }^{11}$ Registre-se que a Constituição Federal elenca as atribuições constitucionais dos Tribunais de Contas, e quanto a isso não se propõe alterações; todavia, a rotina de trabalho no cumprimento da missão constitucional pode ser melhorada, e muito. Para tal, sugerem-se alguns mecanismos, como o termo de ajustamento de gestão (semelhante ao termo de ajustamento de conduta utilizado pelo Ministério Público, viabilizando o apontamento das falhas e a possibilidade de correção de maneira mais célere), auditorias operacionais (auditorias especializadas e mais detalhadas, com equipe multidisciplinar, sistemática que já vem sendo utilizada nas auditorias relacionadas ao meio ambiente e que seria de suma importância ser utilizada na averiguação da aplicação dos recursos destinados a financiar o direito à saúde e à educação), audiências públicas (como,--por exemplo, a fiscalização da efetiva participação da comunidade na elaboração do orçamento e em outros temas atinentes aos direitos fundamentais), intercomunicação entre as instituições (em especial, entre Tribunais de Contas e Judiciário, de maneira a informar se determinado $\mathrm{Mu}$ nicípio, Estado ou a União aplicou o percentual mínimo em educação, viabilizando uma melhor análise das demandas judiciais referentes ao tema).

12 Preocupação que não se restringe apenas ao nosso país: SOUSA, Alfredo José. O Tribunal de Contas de Portugal na actualidade. O Novo Tribunal de Contas: órgão protetor dos direitos fundamentais. Belo Horizonte: Fórum, 2003.

${ }^{13}$ Como forma de aprimorar uma abordagem mais ampla sobre direitos fundamentais, recomendável a obra de SARLET, Ingo Wolfgang. A eficácia dos direitos fundamentais. 10. ed. Porto Alegre: Livraria do Advogado, 2009, em conjunto com as demais obras referidas nas referências bibliográficas. 
certa forma paralelo ao controle interno).$^{14}$ Assim, além do controle externo tradicional (posterior), denota-se a importância de um controle prévio, concomitante e sucessivo. ${ }^{15}$

As Cortes de Contas são órgãos constitucionalmente autônomos, ${ }^{16}$ suas decisões têm traço de definitividade e têm função judicante (não-jurisdicional), ou seja, não apenas administrativa, mas também política. Nesse sentido, o Ministro Carlos Ayres Britto ressalta: "Nenhum Tribunal de Contas é Tribunal singelamente administrativo. Não pode ser um Tribunal tão-somente administrativo um órgão cujo regime jurídico é centralmente constitucional". ${ }^{17}$ Indispensável, portanto, na esfera nacional, os Tribunais de Contas aproveitarem o referido reconhecimento por meio da utilização de novos institutos na tutela da efetividade dos direitos fundamentais.

No âmbito internacional, em especial no cenário europeu, em regra, existem várias espécies de controle: um em nível regional, outro nacional e também um controle comunitário (este, efetuado pelo Tribunal de Contas Europeu). Quan-

${ }^{14}$ Art. 74. Os Poderes Legislativo, Executivo e Judiciário manterão, de forma integrada, sistema de controle interno com a finalidade de:

I - avaliar o cumprimento das metas previstas no plano plurianual, a execução dos programas de governo e dos orçamentos da União;

II - comprovar a legalidade e avaliar os resultados, quanto à eficácia e eficiência, da gestão orçamentária, financeira e patrimonial nos órgãos e entidades da administração federal, bem como da aplicação de recursos públicos por entidades de direito privado;

III - exercer o controle das operações de crédito, avais e garantias, bem como dos direitos e haveres da União;

IV - apoiar o controle externo no exercício de sua missão institucional.

${ }^{15}$ ALMEIDA, José Luís Pinto. Fiscalização prévia, concomitante e sucessiva no quadro das competências do Tribunal de Contas de Portugal. Revista do Tribunal de Contas de Santa Catarina, Florianópolis, v. 5, n. 6, p. 31-50, 2008.

${ }^{16}$ Em razão de o Tribunal de Contas não se enquadrar em nenhum dos três Poderes, na medida em que fiscaliza os três, oportuno denominá-lo de órgão constitucionalmente autônomo, com inspiração nos ensinamentos de MOREIRA NETO, Diogo de Figueiredo. Algumas notas sobre órgãos constitucionalmente autônomos (um estudo de caso sobre os Tribunais de Contas no Brasil). Revista de Direito Administrativo, Rio de Janeiro, n. 223, p. 1-24, jan./mar. 2001.

${ }^{17}$ BRITO, Carlos Ayres. O regime constitucional dos Tribunais de Contas. In: GRAU, Eros Roberto; CUNHA, Sérgio Sérvulo. Estudos de direito constitucional em homenagem a José Afonso da Silva. São Paulo: Malheiros, 2003. p. 97. 
to às Entidades Fiscalizadoras Superiores (EFS), em linhas gerais, detectam-se dois sistemas: um de controle externo unipessoal (Controladorias) e outro colegiado (Tribunais de Contas). ${ }^{18}$

J. J. Gomes Canotilho ${ }^{19}$ aduz uma revisão urgente da jurisdição financeira no quadro de uma Teoria do Estado e da Constituição e a incontornável tarefa de dar centralidade a várias dimensões constitutivas do princípio republicano. ${ }^{20} \mathrm{Con}$ juntamente, na mesma obra, refere que o controlo de contas deve pautar-se por novos padrões de aferimento das contas e alargar o objetivo do controlo explicitando estudos nesse sentido, no que tange à Itália (em que o Tribunal de Contas é elevado a "órgão independente ao serviço do Estado-comunidade"), França (com referências ao papel atual das Cour des Comptes) e Alemanha (que mesmo com tribunais de contas sem jurisdição, exerce fiscalização das decisões financeiras sob o ponto de vista dos princípios da economicidade, eficácia e eficiência).

Demonstradas noções básicas sobre os Tribunais de Contas e respectivas missões constitucionais, aprofunda-se a seguir a possibilidade de atuação da instituição, de maneira a zelar a dignidade da pessoa humana e a efetividade dos direitos fundamentais.

${ }^{18}$ Nesse sentido: MILESKI, Helio Saul. O controle público exercido sobre a atividade financeira e orçamentária do Estado: dados comparativos entre os sistemas de controles exercidos nos âmbitos da União Europeia e do Brasil. Interesse Público, Porto Alegre, n. 53, p. 29-68, 2009.

${ }^{19}$ Em Artigo apresentado na V Assembleia Geral dos Tribunais de Contas da CPLP - Comunidade dos Países de Língua Portuguesa, em Porto, nos dias 8 e 9/5/2008.

${ }^{20}$ CANOTILHO, José Joaquim Gomes. Tribunal de Contas como instância dinamizadora do princípio republicano. Revista do Tribunal de Contas de Santa Catarina, Florianópolis, p. 17-30, set. 2008. O ilustre autor português aborda as dimensões constitutivas do princípio republicano nos seguintes termos: (i) o princípio da responsabilidade (s) financeira; (ii) o princípio da transparência na utilização e gestão dos valores públicos; (iii) o princípio do controlo da boa administração no âmbito do erário público; (iiii) o princípio da justiça intergeracional na partilha dos recursos públicos; (iiiii) o princípio da unidade da República garantidor de autonomia financeira aos entes territoriais autónomos com respeito da coesão económica e territorial, da solidariedade interterritorial e dos vínculos comunitários europeus. 


\section{A tutela da dignidade humana e da efetividade dos Direitos Fundamentais pelos Tribunais de Contas}

A tutela da dignidade da pessoa humana é simultaneamente limite e tarefa dos poderes estatais, nos quais se inserem os Tribunais de Contas (mesmo não sendo um "poder" propriamente dito), e da comunidade em geral, de todos e de cada um, condição dúplice esta que também aponta para uma paralela e conexa dimensão defensiva e prestacional da dignidade. ${ }^{21}$

Ainda, quanto à dignidade humana, importante a ressalva de que é "o Estado que existe em função da pessoa humana, e não o contrário, já que o ser humano constitui a finalidade precípua, e não meio da atividade estatal". ${ }^{22}$ E no que tange a previsão específica em nossa Constituição Federal, em especial no art. $1^{\circ}$, inciso III, contém-se, "não apenas mais de uma norma, mas que esta(s), para além de seu enquadramento na condição de princípio e regra (e valor) fundamental, é (são) também fundamento de posições jurídico-subjetivas, isto é, norma(s) definidora(s) de direitos e garantias, mas também de deveres fundamentais" ${ }^{23}$ (sendo que os deveres fundamentais encontram-se na seara de especial atuação dos Tribunais de Contas, quando da realização do controle externo).

Permanece, portanto, a concepção Kantiana "no sentido de que a dignidade de pessoa humana, esta (pessoa) considerada como fim, e não como meio, repudia

\footnotetext{
${ }^{21}$ SARLET, Ingo Wolfgang. Dignidade da pessoa humana e direitos fundamentais na Constituição Federal de 1988. 7. ed. Porto Alegre: Livraria do Advogado, 2009. p. 52. Em trecho seguinte (p. 67), na obra citada, o autor conceitua dignidade da pessoa humana como "a qualidade intrínseca e distintiva reconhecida em cada ser humano que o faz merecedor do mesmo respeito e consideração por parte do Estado e da comunidade, implicando, neste sentido, um complexo de direitos e deveres fundamentais que assegurem a pessoa tanto contra todo e qualquer ato de cunho degradante e desumano, como venham a lhe garantir as condições existenciais mínimas para uma vida saudável, além de propiciar e promover sua participação ativa e co-responsável nos destinos da própria existência e da vida em comunhão com os demais seres humanos, mediante o devido respeito aos demais seres que integram a rede da vida".

${ }^{22}$ Cf. SARLET, Ingo Wolfgang. Dignidade da pessoa humana e direitos fundamentais na Constituição Federal de 1988. 7. ed. Porto Alegre: Livraria do Advogado, 2009. p. 74.

${ }^{23}$ Cf. SARLET, Ingo Wolfgang. Dignidade da pessoa humana e direitos fundamentais na Constituição Federal de 1988. 7. ed. Porto Alegre: Livraria do Advogado, 2009. p. 77.
} 
toda e qualquer espécie de coisificação e instrumentalização do ser humano". ${ }^{24}$ Imbuídos dessa concepção, os Tribunais de Contas deverão observar a atuação dos administradores, analisando se de fato a dignidade dos administrados é um fim que está sendo buscado. Assim, o controle externo deverá buscar, além da simples análise da aplicação de recursos mínimos estabelecidos na Constituição Federal (no que se refere à saúde e à educação), uma avaliação da eficácia e eficiência dos direitos fundamentais prestados.

Diante da dimensão dúplice da dignidade, a missão do Tribunal de Contas encontra maior papel na esfera da necessidade de sua proteção (assistência) por parte da comunidade e do Estado, "especialmente, quando fragilizada ou até mesmo - e principalmente - quando ausente a capacidade de autodeterminação". ${ }^{25}$

Importante ter em mente a dupla função defensiva e prestacional do dispositivo constitucional que reconhece a dignidade como princípio fundamental, com ênfase na segunda função, ou seja, na imposição de condutas positivas no sentido de promoção e proteção da dignidade, tarefa a ser cumprida incessantemente pelos administradores e fiscalizada em um eficiente controle externo.

Um esclarecimento que se faz necessário é o de que embora a dignidade da pessoa encontre-se conectada à condição humana de cada indivíduo, também há uma dimensão social mais abrangente. ${ }^{26}$ De maneira correlata, há necessidade

${ }^{24}$ Cf. SARLET, Ingo Wolfgang. Dignidade da pessoa humana e direitos fundamentais na Constituição Federal de 1988. 7. ed. Porto Alegre: Livraria do Advogado, 2009. p. 40.

${ }^{25}$ Cf. SARLET, Ingo Wolfgang. Dignidade da pessoa humana e direitos fundamentais na Constituição Federal de 1988. 7. ed. Porto Alegre: Livraria do Advogado, 2009. p. 55, onde o autor refere à dimensão dúplice da dignidade que "manifesta-se enquanto simultaneamente expressão da autonomia da pessoa humana (vinculada à ideia de autodeterminação no que diz com as decisões essenciais a respeito da própria existência), bem como da necessidade de sua proteção (assistência). Dito de outra forma, a dimensão da dignidade como capacidade de autodeterminação e a dimensão assistencial (protetiva).

${ }^{26}$ Para aprofundar estudos referentes à dimensão comunitária (ou sócia), SARLET, Ingo Wolfgang. Dignidade da pessoa humana e direitos fundamentais na Constituição Federal de 1988. 7. ed. Porto Alegre: Livraria do Advogado, 2009. p. 58. 
de cotejar-se a microjustiça com a macrojustiça, ${ }^{27}$ na análise do gerenciamento dos recursos limitados para o atendimento de demandas ilimitadas (em especial no que se refere ao direito à saúde e à educação). A atuação das Cortes de Contas assume maior relevância na dimensão social da concepção de dignidade da pessoa, da mesma forma, predominantemente instrumentaliza-se em uma análise "macro" do gerenciamento dos recursos limitados.

O propósito desta análise inicial é apresentar tópicos necessários para uma melhor visualização da importância de uma tomada de consciência de que as atribuições constitucionais atinentes aos Tribunais de Contas estão a serviço da concretização do princípio da dignidade positivado no art. $1^{\circ}$. inciso III, da Constituição Federal. ${ }^{28}$

Oportuno, à guisa de considerações preliminares atinentes ao segundo tema do presente tópico, delinear alguns comentários sobre a "efetividade" dos direitos fundamentais. É corrente a distinção entre as noções de eficácia jurídica e social, identificando-se esta última com o conceito de efetividade. ${ }^{29}$ Sob outro prisma, há como sustentar a íntima vinculação entre as noções de eficácia jurídica e social (efetividade); a primeira, constituindo pressuposto da segunda. ${ }^{30}$ Assim, define-se, com respaldo nos ensinamentos de Ingo Sarlet, "eficácia jurídica como a possibilidade (no sentido de aptidão) de a norma vigente (juridicamente existente) ser aplicada

${ }^{27}$ Conceitos que serão desenvolvidos na análise de intercomunicação entre instituições em face da consagração dos direitos sociais, com arrimo nos ensinamentos de Ana Paula de Barcellos.

${ }^{28}$ A título informativo, com arrimo nos ensinamentos de SARLET, Ingo Wolfgang. Dignidade da pessoa humana e direitos fundamentais na Constituição Federal de 1988. 7. ed. Porto Alegre: Livraria do Advogado, 2009. p. 70 et. seq., dentre os países da União Europeia, as Constituições da Alemanha, Espanha, Grécia, Irlanda e Portugal consagraram expressamente o princípios da dignidade. De maneira diversa, dentre os países integrantes do Mercosul, apenas o Brasil e Paraguai "guindaram o valor da dignidade ao "status" de norma fundamental," nos dizeres do autor. Ademais, a respeito da universalização da dignidade da pessoa humana e dos direitos fundamentais, BONAVIDES, Paulo. Curso de direito constitucional. 8. ed. São Paulo: Malheiros, 1999. p. 523 et. seq.

${ }^{29}$ SARLET, Ingo Wolfgang. A eficácia dos direitos fundamentais. 10. ed. Porto Alegre: Livraria do Advogado, 2009. p. 237.

${ }^{30}$ SARLET, Ingo Wolfgang. A eficácia dos direitos fundamentais. 10. ed. Porto Alegre: Livraria do Advogado, 2009. p. 239. 
aos casos concretos e de - na medida de sua aplicabilidade - gerar efeitos jurídicos. Já a efetividade, ${ }^{31}$ eficácia social (objeto maior de nossa abordagem) "pode ser considerada como englobando tanto a decisão pela efetiva aplicação da norma (juridicamente eficaz), quanto o resultado concreto decorrente - ou não - desta aplicação. ${ }^{32}$

Complementando-se as noções sobre a efetividade dos direitos fundamentais, oportuno destacar o dispositivo constante no art. 5. $.^{\circ} \S 1 .^{\circ}$ de nossa Constituição, de maneira a não ser subestimado - devendo ser aplicado aos direitos fundamentais sem exceção -, nem superestimado - de forma a ser aplicado tão-somente aos direitos fundamentais e não a todas as normas constitucionais. ${ }^{33}$

O comando constitucional explicitado no art. $5 .^{\circ}, \S 1 .^{\circ}$, da Constituição Federal impõe aos órgãos estatais, incluindo-se os Tribunais de Contas, a missão de maximizar a eficácia dos direitos fundamentais. ${ }^{34}$ Inquestionável, portanto, que

${ }^{31}$ Referente à efetividade das normas constitucionais, encontram-se importantes ponderações na seguinte obra: BARROSO, Luís Roberto. O direito constitucional e a efetividade de suas normas. 9. ed. Rio de Janeiro: Renovar, 2009. Na segunda parte da obra, o autor, ao explicitar conceitos fundamentais para uma nova realidade constitucional, no Capítulo IV, dedica o item 3 ao conceito de "efetividade" (p. 82-86), nos seguintes termos: "A efetividade significa, portanto, a realização do Direito, o desempenho concreto de sua função social. Ela representa a materialização, no mundo dos fatos, dos preceitos legais e simboliza a aproximação, tão íntima quanto possível, entre o dever-ser normativo e o ser da realidade social". Mais adiante, o autor preconiza: "As ideias desenvolvidas nesse capítulo apontam para uma evidência: o Direito existe para realizar-se. Assim, as normas constitucionais devem encontrar em si mesmas a própria tutela e garantia. O doutrinador em estudo rejeita, portanto, a ideia de que o Direito Constitucional seria "um Direito sem sanção", afirmando que as normas constitucionais "articulam-se usualmente na dualidade típica preceito e sanção, quer esta resulte diretamente da regra, quer deflua do sistema em seu conjunto. É precisamente a presença da sanção que garante a eficácia de uma norma jurídica, ensejando sua aplicação coativa quando não é espontaneamente observada. ”

32 SARLET, Ingo Wolfgang. A eficácia dos direitos fundamentais. 10. ed. Porto Alegre: Livraria do Advogado, 2009. p. 240.

${ }^{33}$ Nessa linha de pensamento, SARLET, Ingo Wolfgang. A eficácia dos direitos fundamentais. 10. ed. Porto Alegre: Livraria do Advogado, 2009. p. 268.

${ }^{34}$ Importante, na abordagem da aplicabilidade imediata e eficácia plena dos direitos fundamentais, a seguinte obra: CALIENDO, Paulo. Direito tributário e análise econômica do direito: uma visão crítica. Rio de Janeiro: Elsevier, 2009. p. 168 et seq. 
as Cortes de Contas estão investidas na atribuição constitucional de promover as condições para que os direitos e garantias fundamentais sejam reais e efetivos. ${ }^{35}$

A atuação dos Tribunais de Contas poderá assumir maior destaque no que se refere à efetividade dos direitos fundamentais, por meio do auxílio (mediante a utilização de novos mecanismos de controle externo $)^{36}$ na tomada de decisão pelos administradores públicos na aplicação de normas de direitos fundamentais e mediante a fiscalização do resultado concreto da referida aplicação.

A assertiva de que "todo e qualquer preceito da Constituição (mesmo sendo de cunho programático) é dotado de certo grau de eficácia jurídica e aplicabilidade, consoante a normatividade que lhe tenha sido outorgada pelo Constituinte" ${ }^{37}$ dará suporte às abordagens explicitadas no transcorrer do presente estudo. Da mesma forma, não se pode "desconsiderar a íntima conexão entre a técnica de positivação e a eficácia jurídica"38 e, por consequência, a efetividade dos direitos fundamentais.

Posteriormente, em tópico específico, tratar-se-á da normatividade concedida pelo Constituinte no que se refere aos direitos fundamentais à saúde e à educação, por meio, inclusive, da determinação da aplicação de percentuais

\footnotetext{
${ }^{35}$ Nesse enfoque são as ponderações de SARLET, Ingo Wolfgang. A eficácia dos direitos fundamentais. 10. ed. Porto Alegre: Livraria do Advogado, 2009. p. 268, com arrimo nas lições de F. Piovesan e JJ. Gomes Canotilho, também na p. 270, nos seguintes termos: " [...] a melhor exegese da norma contida no art. $5 .^{\circ}, \$ 1 .^{\circ}$, de nossa Constituição é a que parte da premissa de que se trata de norma de cunho inequivocamente principiológico, considerando-a, portanto, uma espécie de mandado de otimização (ou maximização), isto é, estabelecendo aos órgãos estatais a tarefa de reconhecerem a maior eficácia possível aos direitos fundamentais".

${ }^{36}$ Os referidos mecanismos de controle externo foram referidos em nota anterior, destacando-se mais uma vez a importância das Auditorias Operacionais, que se tratam de auditorias especializadas e detalhadas que possibilitam uma averiguação não somente do cumprimento do princípio da legalidade, mas também uma melhor noção quanto aos resultados efetivos das políticas públicas.

${ }^{37}$ SARLET, Ingo Wolfgang. A eficácia dos direitos fundamentais. 10. ed. Porto Alegre: Livraria do Advogado, 2009. p. 257.

${ }^{38}$ SARLET, Ingo Wolfgang. A eficácia dos direitos fundamentais. 10. ed. Porto Alegre: Livraria do Advogado, 2009. p. 260.
} 
orçamentários mínimos e respectivas sanções, quando do não cumprimento destes, podendo ensejar até mesmo intervenção federal ou estadual.

Importante, portanto, a classificação e respectivas conceituações referentes aos direitos fundamentais trazidas na obra de Ingo Sarlet (2009), que em razão "de sua multifuncionalidade, dividem-se em dois grupos: direitos de defesa (que incluem os direitos de liberdade, igualdade, garantias, bem como parte dos direitos sociais - no caso, as liberdades sociais - e políticos) e os direitos a prestações [...] representados pelos direitos sociais de natureza prestacional - esta última modalidade principal objeto do enfoque que se pretende realizar". ${ }^{39}$

Pode-se afirmar que as garantias institucionais dos Tribunais de Contas estão correlacionadas aos direitos de defesa, as quais necessitarão de ser invocadas na utilização de novos institutos (importantes para a efetivação dos demais direitos fundamentais), implicitamente previstos na Constituição Federal (por meio da teoria dos poderes implícitos, exemplificativamente de maneira a viabilizar a utilização de medidas cautelares, do termo de ajustamento de gestão, dentre outros). Tanto a função precípua como a forma de positivação dada pelo Constituinte serão temas de análise no intento de demonstrar o grau de eficácia dos dispositivos que tratam das Cortes de Contas.

Neste contexto, no presente ensaio, algumas categorias dos direitos fundamentais, com suas cargas eficaciais distintas, serão objeto de análise, com a ressalva de que não somente os direitos prestacionais (enfoque evidente do presente estudo).

A afirmação de Ingo Sarlet no sentido de que "em um mesmo texto de direito fundamental poderão ser extraídas várias normas de direito fundamentais" 40 assumirá grande relevo nas abordagens que se pretende realizar, uma vez que na leitura dos direitos sociais, no mais das vezes, se extrai em conjunto o direito fundamental à boa administração pública.

\footnotetext{
${ }^{39}$ Nesses termos, toma-se a liberdade de apresentar a equação, inspirada em tais assertivas, da seguinte forma: função precípua + forma de positivação = grau de eficácia.

${ }^{40}$ SARLET, Ingo Wolfgang. A eficácia dos direitos fundamentais. 10. ed. Porto Alegre: Livraria do Advogado, 2009. p. 261.
} 
Avaliza-se o referido entendimento, por meio de uma interpretação sistemática e teleológica, que conclui que o constituinte não pretendeu excluir do âmbito do art. 5. $.^{\circ} \$ 1 .^{\circ}$, de nossa Constituição, os direitos políticos, de nacionalidade e os direitos sociais, cuja fundamentalidade parece inquestionável. ${ }^{41}$

Os direitos de defesa são integrados principalmente pelos direitos de liberdade, igualdade, direitos-garantia, garantias institucionais, direitos políticos e posições jurídicas fundamentais em geral, ${ }^{42}$ por tal motivo, a correlação com as garantias institucionais dos Tribunais de Contas, ${ }^{43}$ bem como têm relação direta com o direito fundamental à boa-administração pública.

Já no que diz com os direitos sociais a prestações, Ingo Sarlet inicia a abordagem das especificidades da referida modalidade dos direitos fundamentais aduzindo que o seu "custo assume especial relevância no âmbito de sua eficácia e efetivação". ${ }^{44}$ Registre-se que no presente ensaio serão apresentadas apenas noções sobre os custos e financiamentos dos direitos fundamentais, razão pela qual se remete o leitor a ensinamentos constantes na obra Direitos Fundamentais - orçamento e "reserva do possível”, que tem como organizadores Ingo Sarlet e Luciano Timm. ${ }^{45}$ No próximo item, apresentam-se algumas nuances sobre o tema; ressalve-se, desde já, que não obstante a maioria da doutrina referir-se ao financiamento dos direitos

${ }^{41}$ Nesse sentido, obra citada, p. 262 e na p. 263 nos seguintes termos: “Aliás, a extensão do regime material da aplicabilidade imediata aos direitos fora do catálogo não encontra qualquer óbice no texto constitucional, harmonizando, para, além disso, com a concepção materialmente aberta dos direitos fundamentais consagrada, entre nós”, no art. $5 .^{\circ}, \S 2 .^{\circ}$, da CF.

${ }^{42}$ Cf. SARLET, Ingo Wolfgang. A eficácia dos direitos fundamentais. 10. ed. Porto Alegre: Livraria do Advogado, 2009. p. 274.

${ }^{43}$ As garantiras institucionais dos Tribunais de Contas respaldam a utilização de alguns dos novos institutos propostos no novo controle externo na tutela da efetivação dos direitos fundamentais.

${ }^{44}$ Cf. SARLET, Ingo Wolfgang. A eficácia dos direitos fundamentais. 10. ed. Porto Alegre: Livraria do Advogado, 2009. p. 281 et seq.

${ }^{45}$ SARLET, Ingo Wolfgang; TIMM. Luciano. Direitos fundamentais e orçamento e reserva do possível. Porto Alegre: Livraria do Advogado, 2008. Com ênfase nos artigos dos organizadores, conjuntamente com os de autoria de: Ricardo Lobo Torres, Gustavo Amaral e Danielle Mello, Ana Paula de Barcellos, Paulo Caliendo, Leandro Martins Zanitelli, Ricardo Seibel de Freitas Lima, Jayme Weingartner Neto e Vinícius Diniz Vizzotto, Leonel Pires Ohlweiler, Ricardo Lupion e Malla Pollack. 
fundamentais como "custos", importante mencionar que em razão da essencialidade de alguns direitos fundamentais (como o direito à educação e à saúde) na realidade recomenda-se a leitura de "custos" como sinônimo de "investimento".

\section{A Atuação dos Tribunais de Contas na "Face Oculta dos Direitos Fundamentais"}

Conforme oportuna ponderação de Nabais $(2000),{ }^{46}$ ao se tratar dos direitos fundamentais é de suma importância abordar sua face oculta, que consiste abordar os deveres e os custos que os materializam. Todavia, tais temas não são bem-vindos ao discurso social e político nem à retórica jurídica. Da mesma forma, o controle externo a ser exercido pelos Tribunais de Contas (que têm correlação com o custo dos direitos), não obstante a relevância, não têm sido objeto de estudo doutrinário.

Inquestionável a necessidade de zelo na captação de recursos e o controle (pelos Tribunais de Contas) de maneira a minimizar a renúncia de receitas, mas sem olvidar uma das razões de ser do Estado, que é a realização da dignidade da pessoa humana. Nessa linha, o autor anteriormente referido, recomenda que "o estado fiscal não pode deixar de se configurar como um instrumento, porventura o instrumento que historicamente se revelou mais adequado à materialização desse desiderato". A seguir, Nabais pondera que todos "os direitos fundamentais têm custos financeiros públicos," alguns, de maneira mais explícita, como os direitos sociais (objeto de análise a seguir) e conclui o autor, parafraseando Dworkin, que devemos tomar "a sério os deveres fundamentais e, por conseguinte", devemos tomar " $a$ sério os custos orçamentais de todos os direitos fundamentais". ${ }^{7}$

\footnotetext{
${ }^{46}$ NABAIS, José Casalta. A face oculta dos direitos fundamentais: os deveres e os custos dos direitos. Revista da AGU, Brasília, n. especial, p. 73-92, jun. 2002. Em apertada síntese, informa-se que o autor classifica dos custos em sentido lato (como, por exemplo, o dever de votar) e em custos em sentido estrito (que seria o dever de pagar impostos).

${ }^{47}$ NABAIS, José Casalta. A face oculta dos direitos fundamentais: os deveres e os custos dos direitos. Revista da AGU, Brasília, n. especial, p. 73-92, jun. 2002.
} 
Avalizam-se integralmente tais ponderações, com o acréscimo de que uma das formas de levar a sério os custos dos direitos fundamentais é a máxima otimização da aplicação dos recursos orçamentários e para tal se demonstra salutar um eficiente controle das políticas públicas pelas Cortes de Contas. Nessa senda, no próximo item, serão abordadas considerações sobre o controle das políticas públicas atinentes à saúde e à educação.

\section{A otimização da aplicação dos recursos orçamentários em saúde e educaçâo}

Indispensável a indagação se os Tribunais de Contas, conjuntamente com a mera aplicação dos recursos mínimos previstos na Constituição Federal Brasileira em educação e saúde, também controlam a efetividade dos referidos direitos fundamentais prestacionais. ${ }^{48}$

Conjuntamente questiona-se se a gestão pública realizada pelos entes federativos e o respectivo controle externo exercido pelos Tribunais de Contas, no que tange a prestação dos direitos sociais à saúde e à educação, demonstram-se eficazes e eficientes ou há necessidade de mudança de paradigmas na tutela dos referidos direitos fundamentais sob a ótica do direito fundamental à boa administração pública.

Em uma análise preliminar, depreende-se que a referida mudança de paradigmas, na tutela dos direitos fundamentais à saúde e educação, sob a ótica do direito fundamental à boa administração, demonstra ser uma alternativa para uma

\footnotetext{
${ }^{48}$ O primeiro passo foi dado, ou seja, a importante fiscalização realizada pelos Tribunais de Contas quanto à aplicação do percentual mínimo estabelecido na Constituição Federal pelos Municípios, Estados e União. Todavia, há necessidade de um segundo passo, qual seja, uma averiguação complementar quanto à efetividade da prestação dos direitos fundamentais à saúde e à educação. Para tal, as auditorias operacionais se demonstram essenciais. Da mesma forma, uma maior participação da comunidade, através de audiências públicas, desde a elaboração do orçamento bem como nas etapas seguintes, demonstra ser decisivo para uma conclusão mais específica até que ponto os recursos foram aplicados de maneira eficiente e de forma a satisfazer um mínimo necessário em educação e saúde. Conjuntamente, a troca de informações entre instituições auxiliará em uma fiscalização mais precisa.
} 
maior efetividade dos direitos sociais prestacionais em estudo, antes de outras medidas que ficariam em segundo plano, como o aumento dos percentuais orçamentários (considerando-se a limitação de recursos). Assim sendo, desenha-se a construção de novos institutos de controle de gestão pública.

\section{Os regimes jurídicos do direito fundamental à saúde e à educação na} Constituição Federal de 1988 apresentam pontos de consonância (como se tratarem de exceção à vedação e à vinculação de receita de impostos, ou seja, há determinação constitucional de destinação específica de recursos vinculados, determinando-se percentuais mínimos em saúde e em educação sob pena de intervenção) e de distinções (como existir dispositivos claros sobre o mínimo existencial quanto à educação e não restar delimitado claramente um direito público subjetivo quanto ao direito fundamental à saúde). Contudo, no presente panorama geral, não será possível uma abordagem minuciosa dos referidos regimes jurídicos, somente considerações gerais que se apresentam a seguir.

Especificamente quanto ao regime jurídico do direito fundamental à saúde, previsto nos artigos 6. ${ }^{\circ}$ e 196 a 200, todos da Carta Constitucional, sem o esquecimento do art. 77 do Ato das Disposições Constitucionais Transitórias, apura-se tratar de tema de alta complexidade até mesmo para obras específicas, ${ }^{49}$ restringe-se, portanto, apenas a comentários essenciais para a compreensão da otimização que se pretende dar no presente estudo. Destaca-se a dificuldade em delimitar o reconhecimento de um direito subjetivo individual a prestações na área da saúde. Todavia, o dilema referente ao conteúdo do direito à saúde não é o enfoque que se pretende enfrentar. A preocupação maior refere-se ao argumento costumeiro de "ausência de recursos", mesmo diante de situações em que os administradores sequer aplicaram os recursos mínimos previstos na Constituição Federal; ou se aplicaram o mínimo constitucional estabelecido, situações há em que a destinação

${ }^{49}$ FIGUEIREDO, Mariana F. Direito fundamental à saúde. Parâmetros para sua eficácia e efetividade. Porto Alegre: Livraria do Advogado, 2007.

SARLET, Ingo Wolfgang. Contornos do direito fundamental à saúde na constituição de 1988. Doutrina - Revista PGE, Porto Alegre. v. 25, n. 56, p. 41-62, dez. 2002. .

SARLET, Ingo Wolfgang. Algumas considerações em torno do conteúdo, eficácia e efetividade do direito à saúde na Constituição de 1988. Interesse Público, Porto Alegre, n. 12, p. 91-107, out./dez. 2001. 
não foi efetivada da maneira mais eficiente, de maneira a resguardar conjuntamente o direito fundamental à boa administração pública, ${ }^{50}$ (lembrando-se de uma das nuances do referido direito, que é a necessária proporcionalidade).

O direito social à educação está expressamente previsto no art. $6 .^{\circ}$ da Constituição Federal e também se sujeita ao regime jurídico especial, nos termos do art. $5 .^{\circ}, \S$ $1 .^{\circ}$, e art. 60, $\$ 4 .^{\circ}$, inc. IV, da Carta Constitucional. ${ }^{51}$ Conjuntamente, o direito à educação recebeu tutela específica no capítulo III do título da ordem social (arts. 205 a 214).

A primeira ponderação que se impera é no sentido de que, pelo que possibilita o $\$ 2 .^{\circ}$ do art. $5 .^{\circ}$ da Constituição Federal, alguns dos dispositivos atinentes à educação detêm fundamentalidade com possibilidade de visualização de um núcleo essencial (de maneira distinta do regime conferido à saúde pelo constituinte, que optou por não delimitar claramente um direito público subjetivo).

Sarlet $^{52}$ analisa os dispositivos constitucionais atinentes ao direito à educação em blocos distintos, entendendo que no mínimo quanto aos artigos 205 a 208 da Constituição Federal podemos considerá-los integrantes da essência do direito fundamental à educação, averiguando-se fundamentalidade material e formal. Já

\footnotetext{
${ }^{50}$ Nesta linha, recomendável um aprofundamento sobre o tema, com arrimo na obra de FREITAS, Juarez. Discricionariedade administrativa e o direito fundamental à boa administração pública. 2. ed. São Paulo: Malheiros, 2009, que sintetiza a questão nos seguintes termos: "[...] O direito fundamental à boa administração pública (conceito a ser aqui formulado, sob a inspiração do art. 41 da Carta dos Direitos Fundamentais de Nice), é norma implícita (feixe de princípios e regras) de direta e imediata eficácia em nosso sistema constitucional, a impelir o controlador a fazer às vezes de "administrador negativo", isto é, a terçar armas contra a discricionariedade exercida fora dos limites ou aquém dos limites - a saber, de maneira extremada ou omissa.

${ }^{51}$ Sobre o regime jurídico especial dos direitos sociais, primordial a leitura das seguintes obras: SARLET, Ingo Wolfgang. Os direitos fundamentais sociais e o problema de sua proteção contra o poder de reforma na Constituição de 1988. Revista Direito Público, Porto Alegre, v. 1, n. 2, p. 5-35, out./nov. 2003.

SARLET, Ingo Wolfgang. Os direitos fundamentais sociais na ordem constitucional brasileira. Revista PGE, Porto Alegre, v. 25, n. 55, p. 29-69. jun. 2002.

SARLET, Ingo Wolfgang. Os direitos fundamentais sociais como "cláusulas pétreas". Interesse Público, Porto Alegre, n. 17, p. 56-74, jan./fev. 2003.

${ }^{52}$ SARLET, Ingo Wolfgang. A eficácia dos direitos fundamentais. 10. ed. Porto Alegre: Livraria do Advogado, 2009.
} 
no que se refere aos artigos 209 à 211, entende o autor tratarem-se de "normas de cunho organizacional e procedimental, com status jurídico-positivo idêntico aos das demais normas constitucionais.. ${ }^{53}$ Os artigos 212 e 213 contêm normas estabelecendo metas, prioridades e diretrizes para aplicação e distribuição dos recursos públicos na esfera educacional e o art. 214 estabelece o plano nacional de educação e respectivos objetivos.

Ressalte-se que o $\$ 2 .^{\circ}$ do art. 208 da Constituição Federal determina a possibilidade de responsabilização da autoridade competente pelo não-oferecimento ou oferta irregular desse ensino obrigatório gratuito. Ademais, o art. 227 (e o art. 229 na mesma linha, determinando educação como dever dos pais) prevê como dever da família, da sociedade e do Estado assegurar à criança e ao adolescente, com absoluta prioridade, o direito à educação (e também à saúde). Depreende-se, portanto, que os referidos dispositivos constitucionais trazem uma maior robustez e uma maior densidade normativa ao direito à educação.

A delimitação e tutela especial dada pelo constituinte quanto ao direito fundamental ao ensino público fundamental gratuito resta bem pontuada, não merecendo prosperar sequer argumentos no sentido de haver limite fático da reserva do possível, tangente à ausência de recursos, havendo, inclusive, previsão de destinação específica de recursos e um mínimo a ser aplicado pelos administradores, estabelecido no art. 212 da Constituição Federal.

Registre-se que a louvável densidade normativa não para aí. A seguir, apresenta-se um convite para um rápido e singelo exercício de hermenêutica constitucional, aplicável tanto ao regime jurídico do direito fundamental à educação, como ao regime jurídico do direito fundamental à saúde, ambos previstos em nossa Carta Constitucional.

\footnotetext{
${ }^{53}$ SARLET, Ingo Wolfgang. A eficácia dos direitos fundamentais. 10. ed. Porto Alegre: Livraria do Advogado, 2009. p. 333.
} 
Mediante uma interpretação tópico-sistemática ${ }^{54}$ dos artigos 34, inc. VII, "e", e 35, inc. III, da Constituição Federal (que tratam da previsão de intervenção quando da não-aplicação dos recursos mínimos em educação e saúde) em conjunto com os demais dispositivos constitucionais que tutelam o direito fundamental à educação e à saúde - em especial os que determinam os percentuais mínimos a serem aplicados, como o art. 212 da Constituição Federal e o art. 77 do ADCT e a Emenda Constitucional n. 29/00 - (pelo que permite o art. 167, in. IV, da CF) impera-se a visualização no sentido de que os referidos direitos fundamentais sociais prestacionais assumem uma maior densidade normativa ${ }^{55}$ de maneira a atingir um maior grau de eficácia.

${ }^{54}$ FREITAS, Juarez. A Interpretação sistemática do direito. 5. ed., São Paulo: Malheiros, 2010. Oportuno um respaldo do presente estudo com os "preceitos da boa interpretação tópico-sistemática do Direito Administrativo", abordados por FREITAS, Juarez. A Interpretação sistemática do direito. 5. ed., São Paulo: Malheiros, 2010. p. 242 et seq. Em razão da inquestionável lucidez dos preceitos, citam-se os seguintes tópicos: "(I) A boa interpretação sistemática do Direito Administrativo pressupõe que os princípios, os objetivos e os direitos fundamentais sejam reconhecidos como base e ápice da ordem jurídica, com a possibilidade de suspender ou cortar a eficácia de determinadas regras, sempre que realmente necessário à consecução das finalidades superiores do sistema [...]; (II) A boa interpretação sistemática do Direito Administrativo é aquela que sacrifica o mínimo para preservar o máximo dos princípios, objetivos e direitos fundamentais, vedadas ações e omissões causadoras de danos [...], (III) A boa interpretação sistemática do Direito Administrativo deve favorecer o cumprimento das decisões jurisdicionais consolidadas, salvo motivo explicitado e imperioso em contrário [...]; (IV) A boa interpretação sistemática do Direito Administrativo deve almejar, como ideal regulador, a máxima realização possível dos objetivos fundamentais da República (CF, art. 3.º), com atuação preferencialmente preventiva ou precavida [...]: (V) A boa interpretação sistemática do Direito Administrativo deve ser articulada a partir da hierarquização motivada e imparcial das premissas eleitas [...]; (VI) A boa interpretação sistemática do Direito Administrativo é aquela que pretende ser coerente e aberta, favorável à democracia real, com a salvaguarda do direito fundamental à participação [...]; (VII) A boa interpretação do Direito Administrativo sempre procura zelar pela vitalidade sistemática, sem desprezar o texto, mas indo além dele, como requer o próprio Texto Constitucional [...]; (VIII) A boa interpretação sistemática do Direito Administrativo concebe os direitos fundamentais como totalidade indissociável e, nessa medida, procura restringir as eventuais limitações [...]; (IX) A boa interpretação sistemática do Direito Administrativo sempre colima promover a preservação dos princípios constitucionais, ainda quando em colisão [...]; (X) A boa interpretação sistemática do Direito Administrativo concretiza, ao máximo, o direito fundamental à boa administração pública”.

${ }^{55}$ E nesse ponto, mais uma vez a obra A eficácia dos direitos fundamentais - Uma teoria geral dos direitos fundamentais na perspectiva constitucional da autoria de INGO SARLET é recomendável como ponto de partida. 
Nessa senda, duas tutelas especiais e importantes foram reservadas pelo Constituinte aos direitos fundamentais à saúde e à educação: $i$ ) a possibilidade de destinação de verbas específicas a tutelar ambos os direitos fundamentais (art. 167, inc. IV, da CF); e, ii) a previsão de "sanção constitucional" (pode-se dizer assim) de intervenção da União nos Estados ou Distrito Federal (artigo 34, inc. VII, "e”, da CF) e intervenção dos Estados em seus Municípios (art. 35, inc. III, da Constituição Federal) quando não houver aplicação do mínimo constitucionalmente estabelecido em saúde (art. 77 do ADCT) e em educação (art. 212 da CF).

Além da otimização da eficácia jurídica (possibilidade de as normas vigentes serem aplicadas aos casos concretos) das normas constitucionais referentes aos direitos fundamentais à saúde e à educação que se procurou demonstrar (com destaque na densidade normativa trazida pela cogência estabelecida nos dispositivos que preveem intervenção quando da não-aplicação dos recursos mínimos em educação e saúde), a seguir algumas ponderações na seara da eficácia social - efetividade (que engloba tanto a efetiva aplicação da norma, quanto do resultado concreto decorrente de sua aplicação).

\section{As finanças públicas a serviço dos Direitos Fundamentais}

Os direitos fundamentais têm uma relação direta com as finanças públicas, uma vez que dependem, para a sua integridade e defesa, do equilíbrio da atividade financeira do Estado, ao mesmo tempo em que lhe fornecem o fundamento da legalidade e da legitimidade. Desse modo, "as finanças públicas, em todas as suas dimensões - tributária, patrimonial, monetária, orçamentária, promocional, etc. -, encontram-se em permanente e íntimo contato com os direitos fundamentais".56.

Registre-se que a concretização de direitos fundamentais demanda a realização de despesas públicas e consequentemente exige a arrecadação de recursos para tanto (receita pública). Por tal motivo, demonstra-se importante a observân-

56 TORRES, Ricardo Lobo. Os direitos fundamentais e o Tribunal de Contas. Revista do Tribunal de Contas do Estado do Rio de Janeiro, Rio de Janeiro, n. 23, p. 54-63. 
cia pelos Tribunais de Contas e pela própria sociedade (desde que respeitado o princípio da transparência) das Leis Orçamentárias Anuais (LOA) elaboradas pelos entes públicos, que são veículos normativos que fixam a despesa e estimam a receita para um determinado exercício. As referidas Leis Orçamentárias deverão estar em consonância com a Lei de Diretrizes Orçamentárias (LDO) e o Plano Plurianual, que traçam diretrizes, objetivos, metas e programas dos entes públicos para um determinado exercício. Inquestionável, portanto, a vinculação dos referidos diplomas legais orçamentários com a implementação dos direitos fundamentais, que dependem de ações governamentais, que devem estar inseridas em programas de governo e, consequentemente, prestigiado com recursos suficientes para que sejam alcançados os objetivos traçados. ${ }^{57}$ Em muitas situações, de uma análise prévia (o que corrobora a importância do controle externo preventivo) das leis orçamentárias (genericamente denominadas) já se depreende que não serão investidos os percentuais mínimos orçamentários estabelecidos pela Constituição Federal, no que se refere às verbas que deverão ser destinadas à educação e à saúde.

Diante das considerações necessárias até então explicitadas, referentes à interação dos Tribunais de Contas com os direitos fundamentais, com ênfase nos direitos fundamentais à saúde e à educação (e correlato desenvolvimento social), bem como ao princípio fundamental da dignidade da pessoa humana (desenvolvimento humano), insere-se a seguir uma abordagem referente ao controle das políticas públicas.

\section{Controle das políticas públicas pelos Tribunais de Contas}

As políticas públicas são indispensáveis para a garantia e a promoção de direitos fundamentais e igualmente envolvem gastos e investimentos; como os recursos são limitados, será preciso priorizar e escolher as receitas públicas disponíveis que serão investidas. Dito de outra forma, por Barcellos (2005), "as escolhas em maté-

\footnotetext{
${ }^{57}$ Corroboram, tais assertivas, as considerações de MELLO, João Augusto dos Anjos Bandeira de. Controle externo, lei orçamentária anual e a concretização dos direitos fundamentais. Revista TCE SE, Aracaju, n. 42, p. 26-27, fev./mar. 2009.
} 
ria de gastos públicos não constituem um tema integralmente reservado à liberação política; ao contrário, o ponto recebe importante incidência de normas jurídicas de estatura constitucional". ${ }^{58}$

A referida autora, ao tecer algumas críticas ao controle jurídico e jurisdicional das políticas públicas em matéria de direitos fundamentais, examinando o que intitula crítica operacional, aduz que "ainda que fosse legítimo o controle jurisdicional das políticas públicas, o jurista não disporia do instrumental técnico ou de informação para levá-lo a cabo sem desencadear amplas distorções no sistema de políticas públicas globalmente considerado". 59

Nesse âmbito é que assume relevo a importância do controle externo exercido pelos Tribunais de Contas, ainda mais utilizando-se de novos institutos, dentre eles a intercomunicação entre instituições em face da consagração dos direitos sociais. ${ }^{60}$ Sem adentrarmos na seara da possibilidade ou não do controle jurisdicional das políticas públicas, demonstrar-se-ia relevante a disponibilização ao Poder Judiciário dos dados colhidos no exercício do controle externo efetivado pelos Tribunais de Contas quanto à aplicação dos percentuais mínimos em educação e saúde pelo ente público demandado em juízo. Tais dados poderiam ser considerados, cotejando-se a microjustiça com a macrojustiça, viabilizando uma análise do gerenciamento dos recursos limitados para o atendimento de demandas ilimitadas. $\mathrm{O}$ não atingimento das metas constitucionais quanto à aplicação mínima orçamentária, em demandas que

${ }^{58}$ BARCELLOS, Ana Paula de. Constitucionalização das políticas públicas em matéria de direitos fundamentais: o controle político-social e o controle jurídico no espaço democrático. Revista de Direito do Estado, Rio de Janeiro, v. 1, n. 3, p. 17-54, jul./set. 2006.

${ }^{59}$ BARCELLOS, Ana Paula de. Constitucionalização das políticas públicas em matéria de direitos fundamentais: o controle político-social e o controle jurídico no espaço democrático. Revista de Direito do Estado, Rio de Janeiro, v. 1, n. 3, p. 17-54, jul./set. 2006. p. 34, embasada nos ensinamentos de Richard A. Posner, Economic analysis of law, 1992; Gustavo Amaral, Direito, escassez e escolha - Em busca de critérios jurídicos para lidar com a escassez de recursos e as decisões trágicas, 2001; Flávio Galdino, Introdução à teoria dos custos dos direitos. Direitos não nascem em árvores, 2005.

${ }^{60} \mathrm{Da}$ mesma autora, oportuna a leitura em outra obra da ponderação a respeito que nem sempre será fácil obter informações sobre o destino real dos recursos públicos: BARCELLOS, Ana Paula de. Neoconstitucionalismo, direitos fundamentais e controle das políticas públicas. Revista de Direito Administrativo, Rio de Janeiro, n. 240, p. 83-103, abr./ jun. 2005. 
envolvam saúde e educação, pelo ente público demandado, seria um forte indício a corroborar ou não a possibilidade de êxito na demanda judicial.

Ao traçar os objetos e modalidades de controle, Barcellos (2005), embora não faça menção expressa à atuação dos Tribunais de Contas, mais uma vez traz subsídios que denotam a importância da atuação da referida instituição na tutela da efetividade dos direitos fundamentais. Estabelece a autora os seguintes objetos: “(i) a fixação de metas e prioridades por parte do Poder Público em matéria de direitos fundamentais; (ii) do resultado final esperado das políticas públicas em determinado setor; (iii) a quantidade de recursos a ser investida, em políticas públicas vinculadas à realização de direitos fundamentais; (iv) o atingimento ou não das metas fixadas pelo próprio Poder Público, e (v) a eficiência mínima na aplicação dos recursos públicos destinados a determinada finalidade. ${ }^{61}$

O quinto objetivo, anteriormente referido, - controle da eficiência mínima na aplicação dos recursos - enseja a utilização de outro instituto que merece maiores investigações (considerado como uma nova perspectiva de controle externo a ser exercido pelos Tribunais de Contas) que consiste nas auditorias operacionais. ${ }^{62}$ Somente, mediante uma análise mais apurada, em cotejo com os princípios constitucionais administrativos, ${ }^{63}$ na tutela do direito fundamental à boa administração pública, é que será possível a apuração dos resultados atingidos com a aplicação dos recursos (com especial enfoque, os percentuais mínimos constitucionais aplicados em educação e saúde).

${ }^{61}$ SARLET, Ingo Wolfgang. A eficácia dos direitos fundamentais. 10. ed. Porto Alegre: Livraria do Advogado, 2009. p. 35.

${ }^{62}$ Podemos conceituar auditoria operacional como a avaliação, de forma sistemática, de programas, projetos, atividades ou ações administrativas por órgãos e entidades públicas, quanto às dimensões da economicidade, da eficiência, da eficácia, da efetividade e da equidade de maneira a tutelar o direito fundamental à boa administração pública.

${ }^{63}$ E nesse ponto, de maneira a aprimorar um estudo mais aprofundado sobre o tema, indispensável uma abordagem com respaldo na obra de FREITAS, Juarez. O controle dos atos administrativos e os princípios fundamentais. 4. ed. São Paulo: Malheiros, 2009, em especial o capítulo 1, item 1.4 que explicita o catálogo dos princípios fundamentais regentes das relações de Administração Pública, p. 53 et. seq. 


\section{O princípio da sindicabilidade sistemática dos atos administrativos, pro-} posto por Freitas, ${ }^{64}$ tem relação direta com os controles interno, externo, social e jurisdicional. Da mesma forma, as auditorias operacionais ${ }^{65}$ têm correlação com o referido princípio e visam contornar umas das problemáticas enfrentadas pelos Tribunais de Contas apontadas por Barcellos $(2005)^{66}$ que consiste na demora nas investigações das Cortes de Contas.

Ademais, a efetivação do termo de ajustamento de gestão ${ }^{67}$ viabilizará a célere reparação de danos causados ao erário, possibilitando uma rápida e eficiente correção de irregularidades praticadas na gestão pública, de maneira a valorizar o princípio constitucional da eficiência administrativa e os direitos fundamentais à duração razoável do processo e à boa administração pública.

${ }^{64}$ FREITAS, Juarez. O controle dos atos administrativos e os princípios fundamentais. 4. ed. São Paulo: Malheiros, 2009. p. 112 et. seq. Especificamente quanto ao controle externo exercido pelos Tribunais de Contas o autor faz uma abordagem do art. 71 da Constituição Federal, com destaque ao "caput", incisos IV, VIII, IX, X e parágrafo $2^{\circ}$.

${ }^{65}$ Sobre o tema, importante subsídio encontramos nos estudos de: ALBUQUERQUE, Frederico de Freitas Tenório de. A auditoria operacional e seus desafios: um estudo a partir da experiência do Tribunal de Contas de União. 2006. Dissertação (Mestrado)-Salvador, 2006.

${ }^{66}$ Cf. BARCELlOS, Ana Paula de. Neoconstitucionalismo, direitos fundamentais e controle das políticas públicas. Revista de Direito Administrativo, Rio de Janeiro, n. 240, p. 83-103, abr./jun. 2005. Registre-se, contudo, que ao abordar a atuação dos Tribunais de Contas a referida autora explicita afirmações, que data vênia não concordamos, quando, por exemplo, afirma que as decisões dos Tribunais de Contas podem "sempre" ser revistas pelo Poder Judiciário. Também encontra-se superada a afirmação de que o controle desempenhado pelos Tribunais de Contas concentra-se na verificação da legalidade estrita das contas públicas. Conforme procuramos demonstrar no presente ensaio, em razão da tendência pós-positivista em que se visualiza o direito não apenas como um conjunto de regras, mas como um conjunto de princípios e regras, assumem realce outros princípios além (e não de maneira a excluí-lo) do princípio da legalidade, como o princípio da eficiência, da celeridade e da proporcionalidade, dentre tantos outros indispensáveis à tutela do direito fundamental à boa administração pública.

${ }^{67}$ Sobre o tema: CUNDA, Daniela Zago Gonçalves da. Um breve diagnóstico sobre a utilização do termo de ajustamento de gestão pelos tribunais de contas estaduais. Interesse Público, Porto Alegre, n. 58, p. 243-251, 2010. Estudo que tem como propósito demonstrar a possibilidade da utilização do termo de ajustamento de gestão pelos Tribunais de Contas como decorrência da teoria dos poderes implícitos e também de previsão constitucional explicita, na tutela da efetividade do direito fundamental à boa administração pública e demais direitos fundamentais. 
Nesse rumo, demonstram estar se encaminhando vários dos Tribunais de Contas pesquisados, seja com previsão inserida no regimento interno, como o Tribunal de Contas Estadual de Goiás, como providenciando estudos sobre tal possibilidade, como o Tribunal de Contas do Rio Grande do Sul, que optou pela denominação “termo de adoção de providências”, resultante da terminologia constante na previsão constitucional explicitada no inc. IX do art. 71 da Constituição Federal. ${ }^{68}$

Além dos três institutos abordados (intercomunicação entre instituições, auditorias operacionais e termo de ajustamento de gestão), no que tange ao novo controle externo a ser exercido pelos Tribunais de Contas na tutela da efetividade dos direitos fundamentais, imperam-se reflexões com amparo nas propostas de providências recomendáveis ao aperfeiçoamento do controle externo constantes na obra $^{69}$ de Freitas (2009).

\section{Conclusão}

Pretende-se ter atingido o principal propósito deste ensaio, qual seja, o de ter propiciado alguns passos iniciais de uma necessária marcha rumo a um enfrentamento consciente de vários conceitos atinentes à teoria geral dos direitos fun-

${ }^{68}$ Conforme decisão proferida pelo Pleno do TCE-RS, na Sessão Administrativa de 08/07/2008, da lavra do Cons. Helio Saul Mileski, no processo n. 2257-0200/09-2, aprovando o Parecer n. 14/2009 de autoria do Auditor Substituto de Conselheiro César Santolim e a Informação da Consultoria Técnica n. 14/2009 de autoria dos Auditores Oda Lia da Silveira e Paulo Lourenço Machado.

${ }^{69}$ FREITAS, Juarez. O controle dos atos administrativos e os princípios fundamentais. 4. ed. São Paulo: Malheiros, 2009. p. 14 et. seq. O rol de providências recomendáveis ao aperfeiçoamento do controle externo é explicitado nos seguintes termos: "(1) maior utilização de tecnologia de informação, propícia à realização de controle concomitante; (2) maior sinergia com os demais controles de Estado, no intuito de alcançar efetividade na aplicação das sanções; (3) maior vigilância quanto à economicidade, por intermédio da aludida implantação do sistema nacional de avaliação de custos; (4) introdução normativa do Termo de Ajustamento de Conduta, abrindo canal para a participação da sociedade em processos corretivos acordados, de modo a tornar mais eficaz o cumprimento das metas fiscalizatórias; (5) entrosamento maior dos Tribunais de Contas com os reguladores em geral, numa postura de diálogo e de combate preventivo à corrupção e auditorias operacionais que avancem - cooperativamente - em novos campos, como é exemplo o da seara ambiental [...] (8) o exercício, dentro dos estritos pressupostos, do poder geral de cautela [...]". 
damentais e questões referentes ao controle das políticas públicas, indispensáveis para uma assumida tutela dos direitos fundamentais pelas Cortes de Contas. Conjuntamente, visou-se submeter aos estudos acadêmicos a missão institucional dos Tribunais de Contas e de que forma a referida instituição poderá contribuir para a concretização dos princípios e direitos fundamentais atinentes às suas atividades constitucionalmente estabelecidas.

Procurou-se alinhavar a importância de uma interpretação conjunta dos dispositivos constitucionais que determinam a competência dos Tribunais de Contas (art. 71 e seguintes), sob a ótica dos princípios (art. $1^{\circ}$ ) e objetivos fundamentais (art. $3^{\circ}$ ), além dos princípios da administração pública (art. 37, todos da Constituição Federal de 1988), de maneira a centralizar a atuação da referida instituição na tutela da efetividade dos direitos fundamentais, meta que deverá ser sempre recorrente.

Ao tratar-se da otimização da aplicação dos recursos orçamentários em saúde e educação, elucidou-se uma maior eficácia jurídica das normas constitucionais referentes aos direitos fundamentais à saúde e educação (com destaque na densidade normativa trazida pela cogência estabelecida nos dispositivos que prevêem intervenção quando da não-aplicação dos recursos mínimos em educação e saúde). $\mathrm{Na}$ abordagem dos tópicos, as finanças públicas a serviço dos direitos fundamentais e controle das políticas públicas pelos Tribunais de Contas, almejou-se apresentar algumas ponderações na seara da eficácia social, ou seja, a elucidação de uma possível maior efetividade a ser propiciada pela atuação preventiva e concomitante no controle externo exercido pelos Tribunais de Contas.

Conjuntamente, objetivou-se demonstrar a relevância de o controle público abordar o direito fundamental à boa administração pública e focalizar-se na correlação entre "boa política" e "boa finança". Felizmente, andamentos iniciais nesse sentido têm sido dados pelo Tribunal de Contas da União e de alguns Tribunais de Contas estaduais de nosso país. No mesmo rumo, direcionam-se várias Cortes de Contas da União Europeia (como a de Portugal, da Itália, da França e da Alemanha), de maneira a tutelar os valores previstos nos princípios republicanos. Todavia, tratam-se apenas de primeiros passos e muitos estudos deverão ser desen- 
volvidos ao longo desse novo caminho. Dito de outra forma, a importante fiscalização realizada pelos Tribunais de Contas quanto à aplicação do percentual mínimo estabelecido na Constituição Federal pelos Municípios, Estados e União, já vem sendo realizada pela maioria das Cortes de Contas. Todavia, há necessidade de um segundo passo, qual seja, uma averiguação complementar quanto à efetividade da prestação dos direitos fundamentais à saúde e à educação. Para tal, as auditorias operacionais se demonstram essenciais. Da mesma forma, uma maior participação da comunidade, por meio de audiências públicas, desde a elaboração do orçamento bem como nas etapas seguintes, demonstra ser decisivo para uma conclusão mais específica se de fato os recursos foram aplicados de maneira eficiente e de forma a satisfazer um mínimo necessário em educação e em saúde.

Convém ressaltar, mais uma vez, que a Constituição Federal estabelece as atribuições constitucionais dos Tribunais de Contas, e quanto a isso não se propõe alterações; todavia, a rotina de trabalho no cumprimento da missão constitucional pode ser melhorada e muito. Para tal, foram sugeridos alguns mecanismos, como o termo de ajustamento de gestão (semelhante ao termo de ajustamento de conduta utilizado pelo Ministério Público, viabilizando o apontamento das falhas e a possibilidade de correção de maneira mais célere), auditorias operacionais (auditorias especializadas e mais detalhadas, com equipe multidisciplinar, que seria de suma importância ser utilizada na averiguação da aplicação dos recursos destinados a financiar o direito à saúde e à educação), audiências públicas (como por exemplo, a fiscalização da efetiva participação da comunidade na elaboração do orçamento e em outros temas atinentes aos direitos fundamentais), intercomunicação entre as instituições (em especial, entre Tribunais de Contas e Judiciário, de maneira a informar se determinado Município, Estado ou a União aplicou o percentual mínimo em educação, viabilizando uma melhor análise das demandas judiciais referentes ao tema).

O ensaio, que ora se propôs, é uma singela demonstração da vontade de tornar nossa Constituição Federal uma realidade palpitante, visando além de integrá-la ao nosso cotidiano existencial, tutelar o mínimo existencial nela previsto e ainda com a pretensão de ampliá-lo, por meio da otimização orçamentária, com ênfase nos recursos vinculados em educação e em saúde, tudo sob a ótica especial do direito fundamental à boa administração pública. Para atingir tal propósito, o 
controle das políticas públicas, pelos Tribunais de Contas demonstra ferramenta indispensável, não apenas cingindo-se a um controle da legalidade, indo além, de maneira a zelar o cumprimento de princípios, direitos e deveres fundamentais.

\section{Control of public policies by auditors courts: guardiaship of effectiveness of fundamental rights and duties}

\section{Abstract}

This article, using the deductive method and systemic method, discusses the advantages of a proportional interaction between law, public policies, principles, fundamental rights and duties and the external control to be exercised by the Courts of Auditors, with emphasis on basic rights to health and education (and interrelated development social) as well as the fundamental principle of human dignity (human development). The present study proposes a joint interpretation (topic-systematic) of constitutional articles determining the competence of Audit Courts (article 71 and following of the 1988 Brazilian Federal Constitution) together with the principles (article 1th); and fundamental objectives (Article 3th), and the principles of public administration (art. 37, all of the 1988 Brazilian Federal Constitution), with emphasis on the principle of efficiency (linked to the fundamental right to good public administration) and not only on the principle of legality. The approach emphasizes the optimization of the implementation of budgetary resources towards the expansion of the existential minimum, with regard to fundamental social rights (in particular the right to health and education), so as to circumvent the scarcity of resources. Together, we present brief comments on the audit courts in the national and international context, notes about the control of public policy and some highlights of public finance at the service of fundamental rights. The proposed test is a simple demonstration of the will to make our Constitution a reality throbbing, and aim at integrating it to our everyday existence, defending the existential minimum laid down therein and with the intention to extend it by optimizing budget, with emphasis on resources related to education and health, all from the perspective of the particular fundamental right to good public administration. To achieve this purpose the control of public policies by the Court of Accounts is shown indispensable tool, not just limited itself to a control of legality, 
going beyond, in order to ensure compliance with principles, fundamental rights and fundamental duties.

Keywords: Public Policy. Courts of Accounts. Fundamental rights.

\section{Referências}

ALEXY, Robert. Teoria dos direitos fundamentais. São Paulo: Malheiros, 2008.

ALMEIDA, José Luís Pinto. Fiscalização prévia, concomitante e sucessiva no quadro das competências do Tribunal de Contas de Portugal. Revista do Tribunal de Contas de Santa Catarina, Florianópolis, v. 5, n. 6, p. 31-50, 2008.

ANDRADE, José Carlos Vieira de. Os direitos fundamentais na Constituição Portuguesa de 1976. Coimbra: Almedina, 2005.

ARANGO, Rodolfo. Direitos fundamentais sociais, justiça constitucional e democracia. Revista do Ministério Público do Rio Grande do Sul, Porto Alegre, n. 56, set./dez. 2005.

ÁVILA, Humberto. Teoria dos princípios: da definição à aplicação dos princípios jurídicos. 4. ed. São Paulo: Malheiros, 2005.

ÁVILA, Humberto. A teoria dos princípios e o direito tributário. Revista Dialética de Direito Tributário, São Paulo, n. 125, p. 33-49, fev. 2006.

ÁVILA, Humberto. Moralidade, razoabilidade e eficiência na atividade administrativa. Revista Brasileira de Direito Público, Belo Horizonte, n. 1, p. 105133, abr./jun. 2003.

ÁVILA, Humberto. Neoconstitucionalismo: entre a ciência do direito e o direito da ciência. Revista Brasileira de Direito Público, Belo Horizonte, n. 23, p. 9-30, out./ dez. 2008.

BARCELLOS, Ana Paula de. Neoconstitucionalismo, direitos fundamentais e controle das políticas públicas. Revista de Direito Administrativo, Rio de Janeiro, n. 240, p. 83-103, abr./jun. 2005.

BARCELlOS, Ana Paula de. Constitucionalização das políticas públicas em matéria de direitos fundamentais: o controle político-social e o controle jurídico 
no espaço democrático. Revista de Direito do Estado, Rio de Janeiro, v. 1, n. 3, p. 17-54, jul./set. 2006.

BARRETO, Pedro Humberto Teixeira. O sistema Tribunais de Contas e instituições equivalentes: um estudo comparativo entre o modelo brasileiro e o da União Europeia. Rio de Janeiro: Renovar, 2004.

BARROSO, Luís Roberto. O direito constitucional e a efetividade de suas normas. 9. ed. Rio de Janeiro: Renovar, 2009.

BONAVIDES, Paulo. Curso de direito constitucional. 8. ed. São Paulo: Malheiros, 1999.

BUCCI, Maria Paula Dallari. Notas para uma metodologia jurídica de análise de políticas públicas. Fórum Administrativo, Belo Horizonte, ano 9, n. 104, p. 20-34, out. 2009.

BUCCI, Maria Paula Dallari. Controle judicial de políticas públicas: possibilidades e limites. Fórum Administrativo: Direito Público, Belo Horizonte, n. 103, p. 7-16, set 2009.

BUCCI, Maria Paula Dallari. Direito administrativo e políticas públicas. São Paulo: Saraiva, 2002.

BUCCI, Maria Paula Dallari. O art. 209 da Constituição 20 anos depois. Estratégias do poder executivo para a efetivação da diretriz da qualidade da educação superior. Fórum Administrativo: Direito Público, Belo Horizonte, n. 105, p. 48-63, nov. 2009.

BUCCI, Maria Paula Dallari. O plano de atendimento à saúde (PAS) e o abuso das formas jurídicas. Revista de Direito Administrativo, Rio de Janeiro, n. 208, p. 111137, abr./jun. 1997.

CALIENDO, Paulo. Direito tributário e análise econômica do direito: uma visão crítica. Rio de Janeiro: Elsevier, 2009.

CALIENDO, Paulo. Direito tributário: três modos de pensar a tributação: elementos para uma teoria sistemática do Direito Tributário. Porto Alegre: Livraria do Advogado, 2009.

CANOTILHO, José Joaquim Gomes. Tribunal de Contas como instância dinamizadora do princípio republicano. Revista do Tribunal de Contas de Santa Catarina, Florianópolis, p. 17-30, set. 2008. 
CANOTILHO, José Joaquim Gomes. Neoconstitucionalismo e o estado de direito. Revista Consulex, Brasília, n. 297, p. 6-9, maio 2009.

CANOTILHO, José Joaquim Gomes. O Estado adjetivado e a teoria da Constituição. Interesse Público, Porto Alegre, n. 17, p. 13-24, jan./fev. 2003.

CUNDA, Daniela Zago Gonçalves da. Um breve diagnóstico sobre a utilização do termo de ajustamento de gestão pelos tribunais de contas estaduais. Interesse Público, Porto Alegre, n. 58, p. 243-251, 2010.

DWORKIN, Ronald. O império do direito. São Paulo: M. Fontes, 1999.

DWORKIN, Ronald. Los derechos em serio. Barcelona: Ariel. 1999.

FREITAS, Juarez. A Interpretação sistemática do direito. 5. ed., São Paulo: Malheiros, 2010 .

FREITAS, Juarez. O controle dos atos administrativos e os princípios fundamentais. 4. ed. São Paulo: Malheiros, 2009.

FREITAS, Juarez. Discricionariedade administrativa e o direito fundamental à boa administração pública. 2. ed. São Paulo: Malheiros, 2009.

GRAU, Eros Roberto; CUNHA, Sérgio Sérvulo. Estudos de direito constitucional em homenagem a José Afonso da Silva. São Paulo: Malheiros, 2003.

HOMERCHER, Evandro T. O tribunal de contas e o controle da efetividade dos direitos fundamentais. Interesse Público, Porto Alegre, n. 35, p. 315-343, jan./fev. 2006.

MELLO, João Augusto dos Anjos Bandeira de. Controle externo, lei orçamentária anual e a concretização dos direitos fundamentais. Revista TCE SE, Aracaju, n. 42, p. 26-27, fev./mar. 2009.

MILESKI, Helio Saul. Controle da gestão pública. São Paulo: Revista dos Tribunais, 2003.

MILESKI, Helio Saul. O controle público exercido sobre a atividade financeira e orçamentária do Estado: dados comparativos entre os sistemas de controles exercidos nos âmbitos da União Europeia e do Brasil. Interesse Público, Porto Alegre, n. 53, p. 29-68, 2009. 
MORAES, Germana de Oliveira. Controle jurisdicional da administração pública. 2. ed. São Paulo: Dialética, 2004.

MOREIRA NETO, Diogo de Figueiredo. Quatro paradigmas do direito administrativo pós-moderno: legitimidade. Finalidade. Eficiência. Resultados. Belo Horizonte: Fórum, 2008.

MOREIRA NETO, Diogo de Figueiredo. Algumas notas sobre órgãos constitucionalmente autônomos (um estudo de caso sobre os Tribunais de Contas no Brasil). Revista de Direito Administrativo, Rio de Janeiro, n. 223, p. 1-24, jan./ mar. 2001.

MOTTA, Fabrício. Tribunais de Contas e a efetivação dos direitos fundamentais. Revista Del Rey Jurídica, Belo Horizonte, v. 7, n. 14, p. 36-37, 1. sem. 2005.

NABAIS, José Casalta. A face oculta dos direitos fundamentais: os deveres e os custos dos direitos. Revista da AGU, Brasília, n. especial, p. 73-92, jun. 2002.

RODRIGUES, Daniel dos Santos. Fundamentalidade dos direitos sociais prestacionais e a teoria de direitos humanos de Amartya Sen. Direito Público, Porto Alegre, n. 26, p. 42-52, mar./abr. 2009.

SARLET, Ingo Wolfgang. A eficácia dos direitos fundamentais. 10. ed. Porto Alegre: Livraria do Advogado, 2009.

SARLET, Ingo Wolfgang. Dignidade da pessoa humana e direitos fundamentais na Constituição Federal de 1988. 7. ed. Porto Alegre: Livraria do Advogado, 2009.

SARLET, Ingo Wolfgang; TIMM. Luciano. Direitos fundamentais e orçamento e reserva do possível. Porto Alegre: Livraria do Advogado, 2008.

SARLET, Ingo Wolfgang. Algumas considerações em torno do conteúdo, eficácia e efetividade do direito à saúde na Constituição de 1988. Interesse Público, Porto Alegre, v. 3, n. 12, p. 91-107, out./dez. 2001.

SARLET, Ingo Wolfgang. As dimensões da dignidade da pessoa humana: construindo uma compreensão jurídico-constitucional necessária e possível. In: SARLET, Ingo Wolfgang (Org.). Dimensões da dignidade: ensaios de filosofia do direito e direito constitucional. Porto Alegre: Livraria do Advogado, 2005.

SARLET, Ingo Wolfgang. A eficácia do direito fundamental à segurança jurídica: Dignidade da pessoa humana, direitos fundamentais e proibição do retrocesso 
social no direito constitucional brasileiro. Revista Brasileira de Direito Público RBDP, Belo Horizonte, v. 3, n. 11, p. 111-156, out./dez. 2005.

SARLET, Ingo Wolfgang. A eficácia do direito fundamental à segurança jurídica: dignidade da pessoa humana, direitos fundamentais e proibição de retrocesso social no direito constitucional brasileiro. Revista Brasileira de Direito Público RBDP, Belo Horizonte, ano 3, n. 11, p. 111-156, out./dez. 2005.

SARLET, Ingo Wolfgang. A reforma do judiciário e os tratados internacionais de direitos humanos: observações sobre o $\$ 3^{\circ}$ do art. $5^{\circ}$ da constituição. Interesse Público, Porto Alegre, v. 8, n. 37, p. 49-64, maio/jun. 2006.

SARLET, Ingo Wolfgang; FENSTERSEIFER, Tiago. A tutela do ambiente e o papel do poder judiciário à luz da constituição federal de 1988. Interesse Público, Belo Horizonte: Fórum, ano 10, n. 50, p. 17-43, jul./ago. 2008

SARLET, Ingo Wolfgang; FENSTERSEIFER, Tiago. Algumas Notas sobre a Dimensão Ecológica da Dignidade da Pessoa Humana e sobre a Dignidade da Vida em Geral. Direito Público, Porto Alegre, v. 5, n. 19, p. 7-26, jan./fev. 2008.

SARLET, Ingo Wolfgang. ; FENSTERSEIFER, Tiago. O papel do poder judiciário dos direitos e deveres socioambientais. Revista de Direito Ambiental - RDA, n. 52, p. 73-100, 2008.

SARLET, Ingo Wolfgang. Contornos do direito fundamental à saúde na constituição de 1988. Revista PGE, Porto Alegre. v. 25, n. 56, p. 41-62, dez. 2002

SARLET, Ingo Wolfgang. Direitos fundamentais e direito privado: algumas considerações em torno da vinculação dos particulares aos direito fundamentais. In: _. A constituição concretizada: construindo pontes com o público e o privado. Porto Alegre: Livraria do Advogado, 2000. p. 107-163.

SARLET, Ingo Wolfgang. Os direitos fundamentais, a reforma do judiciário e os tratados internacionais de direitos humanos: notas em torno do $\$ \$ 2^{\circ}$ e $3^{\circ}$ do

art. $5^{\circ}$ da constituição de 1988. Revista de Direito do Estado, Rio de Janeiro, ano 1, n. 1, p. 59-88, jan./mar. 2006.

SARLET, Ingo Wolfgang. Os direitos fundamentais sociais e o problema de sua proteção contra o poder de reforma na Constituição de 1988. Direito Público, Porto Alegre, v. 1, n. 2, p. 5-35, out./dez. 2003. 
SARLET, Ingo Wolfgang. Os direitos fundamentais sociais na ordem constitucional brasileira. Revista PGE, Porto Alegre, v. 25, n. 55, p. 29-69, jun. 2002.

SARLET, Ingo Wolfgang. Os direitos fundamentais sociais como "cláusulas pétreas". Interesse Público, Porto Alegre, v. 5, n. 17, p. 56-74, jan./fev. 2003.

SARMENTO, Daniel. O neoconstitucionalismo no Brasil: riscos e possibilidades. Biblioteca Digital Revista Brasileira de Estudos Constitucionais - RBEC, Belo Horizonte, ano 3, n. 9, jan./mar. 2009.

Disponível em: http://www.editoraforum.com.br/bid/bidConteudoShow. aspx?idConteudo=56993. Acesso em: 20 de maio de 2010 .

SOUSA, Alfredo José. O Tribunal de Contas de Portugal na actualidade. O Novo Tribunal de Contas: órgão protetor dos direitos fundamentais. Belo Horizonte: Fórum, 2003.

TORRES, Ricardo Lobo. Os direitos fundamentais e o Tribunal de Contas. Revista do Tribunal de Contas do Estado do Rio de Janeiro, Rio de Janeiro, v. 13, n. 23, p. 54-63, jul. 1992. 


\section{Para publicar na revista Brasileira de Políticas Públicas, acesse 0 endereço eletrônico www.publicacoesacademicas.uniceub.br. Observe as normas de publicação, para facilitar e agilizar o trabalho de edição.}

